Nevada

Environmental

Restoration

Project

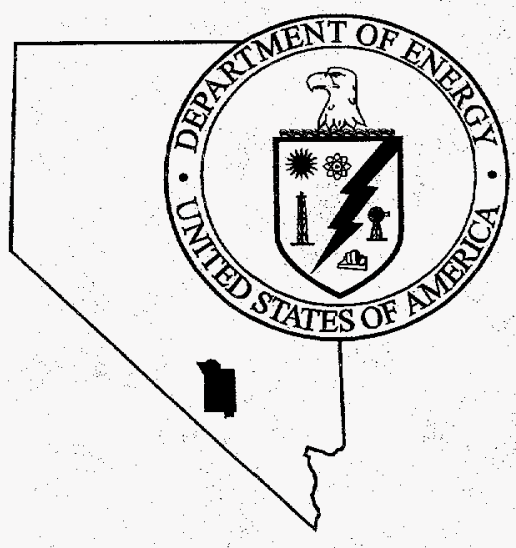

\title{
Closure Report for Housekeeping Category Corrective Action Unit 354 Nevada Test Site
}

Controlled Copy No.

Revision: 0

MASTER

January 1998

OSTABBUTION OF THIS DOCUMENT IS UMUMUTIED
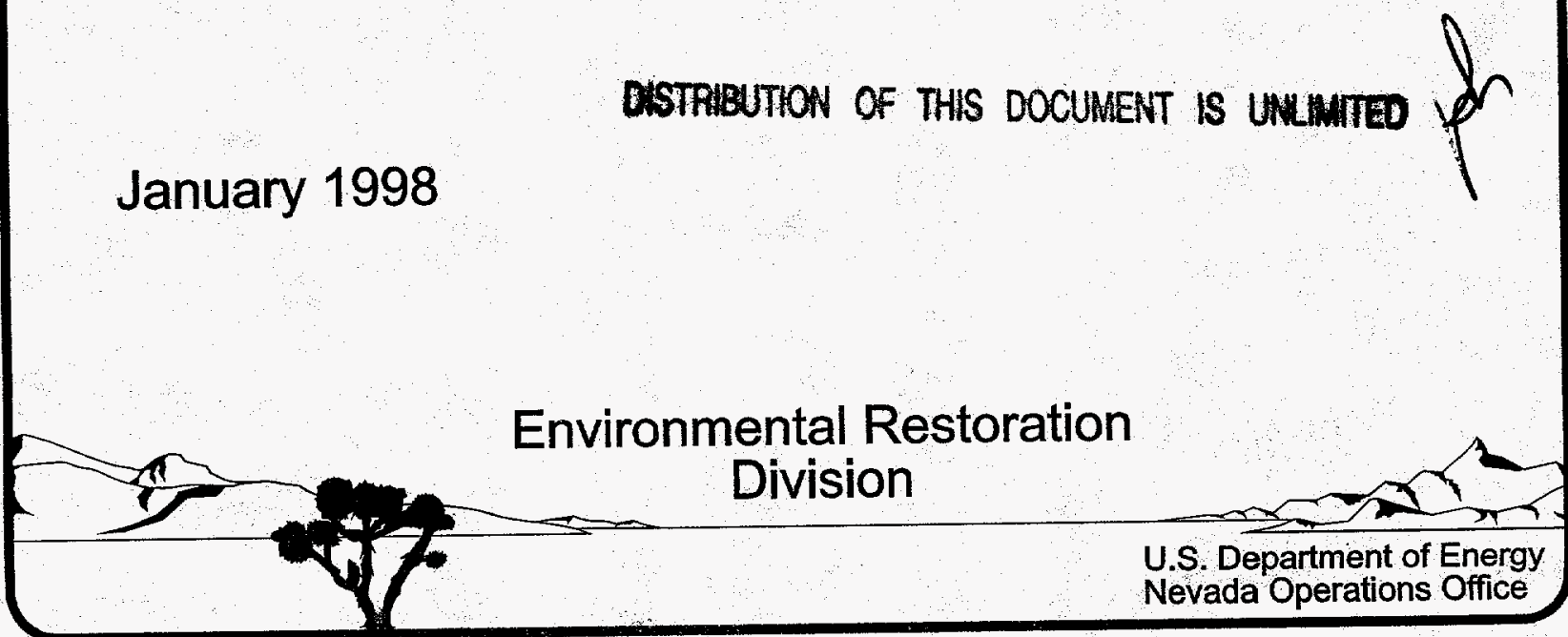


\section{DISCLAIMER}

This report was prepared as an account of work sponsored by an agency of the United States Government. Neither the United States Government nor any agency thereof, nor any of their employees, makes any warranty, express or implied, or assumes any legal liability or responsibility for the accuracy, completeness, or usefulness of any information, apparatus, product, or process disclosed, or represents that its use would not infringe privately owned rights. Reference herein to any specific commercial product, process, or service by trade name, trademark, manufacturer, or otherwise does not necessarily constitute or imply its endorsement, recommendation, or favoring by the United States Government or any agency thereof. The views and opinions of authors expressed herein do not necessarily state or reflect those of the United States Government or any agency thereof. 


\section{DISCLAIMER}

Portions of this document may be illegible in electronic image products. Images are produced from the best available original document. 


\title{
CLOSURE REPORT FOR HOUSEKEEPING CATEGORY CORRECTIVE ACTION UNIT 354 NEVADA TEST SITE
}

\author{
Prepared for \\ U.S. Department of Energy \\ Nevada Operations Office \\ Under Contract No. DE-AC08-96NV11718
}

Controlled Copy No.:

Revision: 0

Prepared by

Bechtel Nevada

Environmental Restoration

January 1998 
This Closure Report is prepared in accordance with the Work Plan for Closure Verification of FFACO Housekeeping Corrective Action Sites/Units(DOE/DoD, 1996). This Closure Report summarizes the corrective actions which were completed at ten Corrective Action Sites within Corrective Action Unit 354. This Closure Report is subject to review and approval by the Nevada Division of Environmental Protection. 


\section{FFACO HOUSEKEEPING CATEGORY CORRECTIVE ACTION UNIT 354}

\begin{tabular}{|c|c|c|}
\hline QAS, WUABER & DESCRIPTHON OF CAS & $5014 \times 65$ \\
\hline $25-22-03$ & (35) Drums & $\begin{array}{l}\text { Drums had previously } \\
\text { been removed. } \\
\text { Remaining debris was } \\
\text { retrieved and disposed. } \\
\text { Lead materials, from CASs } \\
25-26-10 \text { and } 25-26-26 \text {, } \\
\text { were retrieved for } \\
\text { recycling. No further } \\
\text { action required. }\end{array}$ \\
\hline $25-24-14$ & (2) Batteries & $\begin{array}{l}\text { Materials had previously } \\
\text { been removed. No further } \\
\text { action required. }\end{array}$ \\
\hline $25-24-17$ & (2) Batteries & $\begin{array}{l}\text { Materials were retrieved } \\
\text { and recycled. No further } \\
\text { action required. }\end{array}$ \\
\hline $25-24-18$ & Battery & $\begin{array}{l}\text { The broken battery and } \\
\text { lead materials (found in } \\
\text { the vicinity) were retrieved } \\
\text { and recycled. Additional } \\
\text { cleanup at nearby CAS } \\
25-26-21 \text { was also } \\
\text { conducted. No further } \\
\text { action required. }\end{array}$ \\
\hline $25-27-02$ & Drums & $\begin{array}{l}\text { Drums containing PCB } \\
\text { waste had previously been } \\
\text { removed. Lead materials } \\
\text { found in the vicinity were } \\
\text { retrieved and recycled. } \\
\text { No further action required. }\end{array}$ \\
\hline $25-99-15$ & Highway flares & $\begin{array}{l}\text { Items had previously been } \\
\text { removed. No further } \\
\text { action required. }\end{array}$ \\
\hline
\end{tabular}




\section{FFACO HOUSEKEEPING CATEGORY CORRECTIVE ACTION UNIT 354}

\begin{tabular}{|c|c|c|}
\hline CASUUMBER & DESCRIPUON OF CAS & SHAYUS. \\
\hline $25-99-17$ & (4) Gas bottles & $\begin{array}{l}\text { Three of the gas cylinders } \\
\text { were found to be empty, } \\
\text { and one contained } \\
\text { compressed air. After } \\
\text { sampling the air, the } \\
\text { cylinder was emptied and } \\
\text { the assembly disposed in } \\
\text { the landfill. No further } \\
\text { action required. }\end{array}$ \\
\hline $26-99-02$ & (4) Smoke pots & $\begin{array}{l}\text { Most of the smoke pots } \\
\text { had previously been } \\
\text { removed. The remaining } \\
\text { smoke pots were retrieved } \\
\text { and disposed at the Area } \\
11 \text { EODU. No further } \\
\text { action required. }\end{array}$ \\
\hline $27-22-01$ & (5) Drums & $\begin{array}{l}\text { Items had previously been } \\
\text { removed. No further } \\
\text { action required. }\end{array}$ \\
\hline $27-22-02$ & Drum; Fuel Can & $\begin{array}{l}\text { Items had previously been } \\
\text { removed. No further } \\
\text { action required. }\end{array}$ \\
\hline
\end{tabular}




\section{FFACO CORRECTIVE ACTION SITE HOUSEKEEPING CLOSURE VERIFICATION FORM}

Closure Verification Date: $30-A P R-97$

CAS Number: $25-22-03$

General Location: Treatability Test Facility

CAU Number: 354

Latitude:

Elevation:

Longitude:

Northing:

Easting:

Coordinate/Elevation Data Obtained from Garmen 40 Global Position System: Accuracy is within $300 \mathrm{ft}$ Horizontal - Vertical Varies with Locality

Site Access Route: From Mercury, proceed SW on Jackass Flats Rd to Area 25, through Gate 500. Proceed north on C-Rd, and follow as t curves east into F-Rd. The Treatability Test Facility (TTF), Bldg. 3124, is located on the left (north) side of the road inside a hurricane fence. A marker for this CAS is attached to the front gate.

\begin{tabular}{|l|l|}
\hline \multicolumn{1}{|c|}{ Waste Item(s) Originally at Site } & \multicolumn{1}{c|}{ Apparent Waste Type* $^{*}$} \\
\hline (35) Drums & Unknown \\
\hline
\end{tabular}

- Ordinary, Scrap Metal, Asbestos, PCB, Salvageable, Hazardous, Radioactive, Mixed, Unknown, Other.

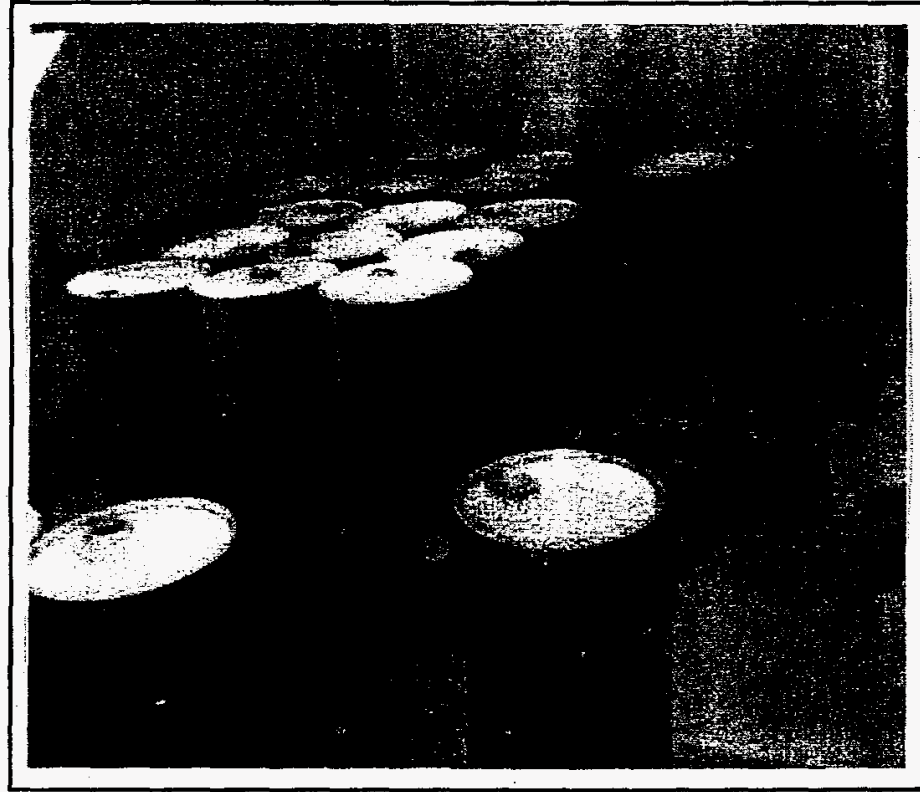

CAS Prior to Cleanup

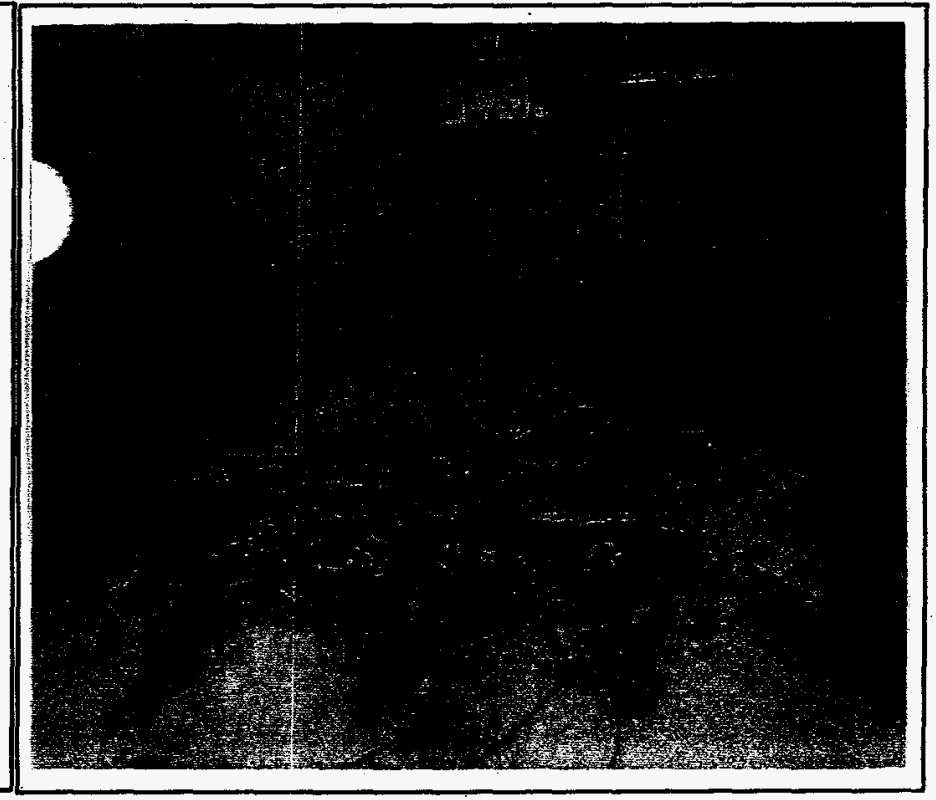

CAS After Cleanup

Current Site Description/Observations: Originally identified on 29-OCT-90, it was verified that the drums had been removed. During the demobilization of this facility, NTS personnel conducted cleanup operations on 11-SEP-97 and retrieved the remaining solid waste debris shown in the photograph (right photo). The debris was disposed at the Area 9 U10c Landfill. Lead bricks and sheets, previously identified as CASs 25-26-10 and 25-26-26 but not relinquished until recently, were recycled through Property and Supply.

No Further Action Required at Corrective Action Site

C. Carlos Gonzales

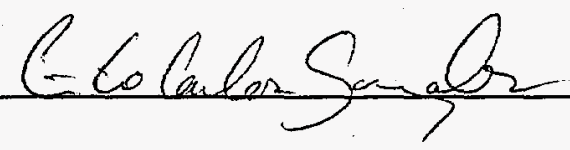

Corrective Action Coordinator/Designee
(Signature)
$1-6-98$

Date 


\title{
FFACO CORRECTIVE ACTION SITE HoUSEKEEPING ClOSURE VERIFICATION FORM
}

Closure Verification Date: 01-MAY-97

CAS Number: 25-24-14

General Location: X-Tunnel Road

Latitude:

Longitude:

\author{
CAU Number: 354 \\ Elevation: \\ Northing: \\ Easting:
}

Coordinate/Elevation Data Obtained from Garmen 40 Global Position System: Accuracy is within $300 \mathrm{ft}$ Horizontal - Vertical Varies with Locality

Site Access Route: From Mercury, proceed SW on Jackass Flats Rd to Area 25, through Gate 500. Turn left (west) onto Lathrop Wells Rd for $5.8 \mathrm{mi}$ to X-Tunnel Rd. Turn left (south) and proceed to storage yard on right side of road prior to arriving at portal area. A CAS marker identifies the former location of the batteries.

\begin{tabular}{|l|l|}
\hline \multicolumn{1}{|c|}{ Waste Item(s) Originally at Site } & \multicolumn{1}{c|}{ Apparent Waste Type* $^{\text {A }}$} \\
\hline (2) Batteries & Recyclable \\
\hline
\end{tabular}

- Ordinary, Scrap Metal, Asbestos, PCB, Salvageable, Hazardous, Radioactive, Mixed, Unknown, Other

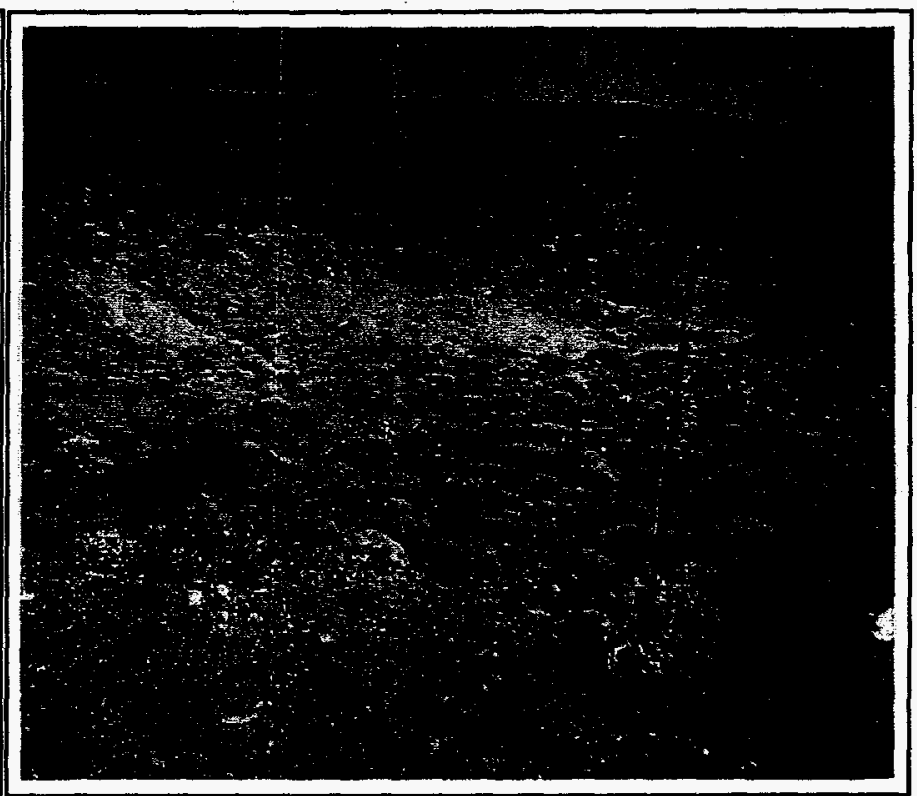

CAS After Cleanup

Current Site Description/Observations: Originally identified by DOE/EPD, field crews verified the presence of two batteries at this location on 23-MAY-95. NTS personnel verified that the batteries had been removed. A CAS marker identifies the former location in the storage yard.

No Further Action Required at Corrective Action Site

C. Carlos Gonzales
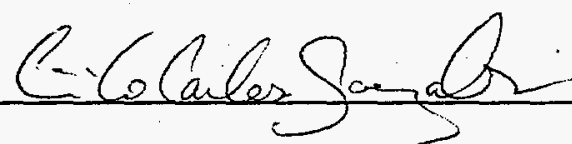

(Signature) $1-6-98$ 


\section{FFACO CORRECTIVE ACTION SITE HOUSEKEEPING ClOSURE VERIFICATION FORM}

Closure Verification Date: 08 -AUG-97.

CAS Number: 25-24-17

General Location: Engine Test Stand \#1

Latitude:

Longitude:

\author{
CAU Number: 354 \\ Elevation: \\ Northing: \\ Easting:
}

Coordinate/Elevation Data Obtained from Garmen 40 Global Position System: Accuracy is within $300 \mathrm{ft}$ Horizontal - Vertical Varies with Locality

Site Access Route: From Mercury, proceed SW on Jackass Flats Rd to Area 25, through Gate 500. Proceed north on C-Rd and turn left (west) on H-Rd. Proceed to K-Rd and turn right (north) to the Engine Test Stand (ETS) \#1. Take the dirt road along the east side of the fenced compound and continue up the hill, turning right (east) when reaching the ravine.

\begin{tabular}{|l|l|}
\hline \multicolumn{1}{|c|}{ Waste Item(s) Originally at Site } & \multicolumn{1}{c|}{ Apparent Waste Type* } \\
\hline (2) Batteries & Recyclable \\
\hline
\end{tabular}

* Ordinary, Scrap Metal, Asbestos, PCB, Salvageable, Hazardous, Radioactive, Mixed, Unknown, Other

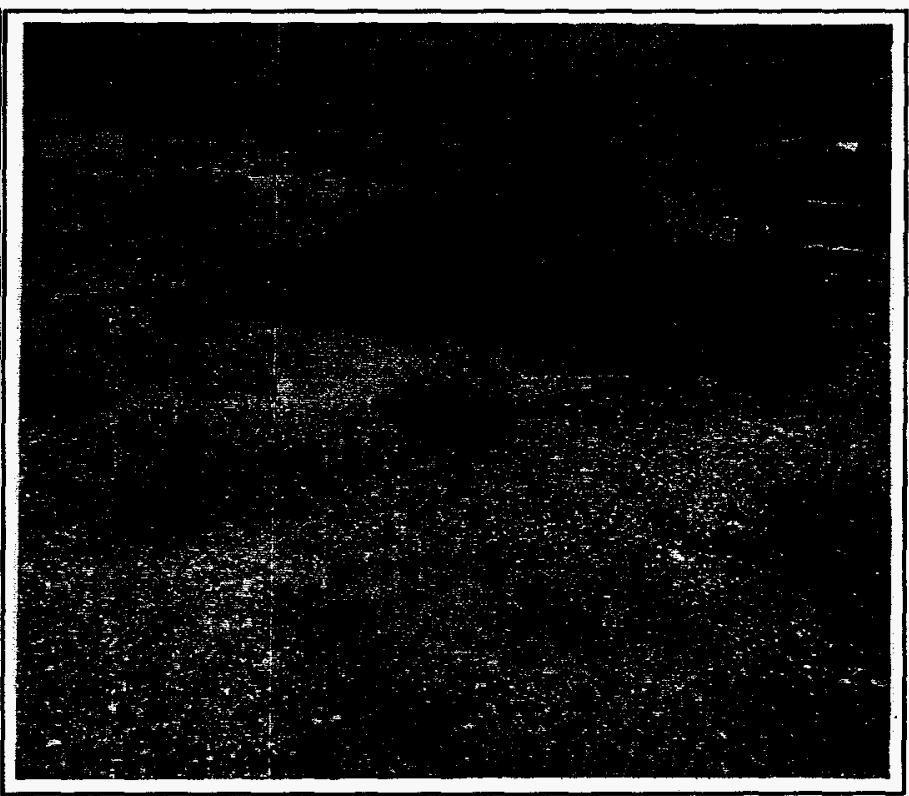

CAS After Cleanup

Current Site Description/Observations:Field crews identified this site while conducting GPS coordinates on a nearby CAS (25-24-04) on 24-JUN-93. NTS personnel verified that the batteries were still present and retrieved them for recycling through Fleet Operations. The associated wood boxes, cables, and debris were disposed in the Area 23 Landfill.

No Further Action Required at Corrective Action Site

C. Carlos Gonzales

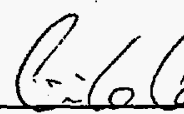

Corrective Action Coordinator/Designee

(Signature) $1-6-88$ 


\section{FFACO CORRECTIVE ACTION SITE HOUSEKEEPING CLOSURE VERIFICATION FORM}

Closure Verification Date: 14-SEP-97

CAS Number: 25-24-18

General Location: Engine Test Stand \#l

Latitude:

Longitude:

\author{
CAU Number: 354 \\ Elevation: \\ Northing: $757,430.302$ \\ Easting: $604,115.787$
}

Coordinate/Elevation Data Obtained from Garmen 40 Global Position System: Accuracy is within $300 \mathrm{ft}$ Horizontal - Vertical Varies with Locality

Site Access Route: From Mercury, proceed SW on Jackass Flats Rd to Area 25, through Gate 500. Proceed north on C-Rd and turn left (west) on H-Rd. Proceed to K-Rd and turn right (north) to the Engine Test Stand (ETS) \#1. Inside gate, turn left (west) and proceed approximately 100 yards.

\begin{tabular}{|c|c|}
\hline Waste Item(s) Originally at Site & Apparent Waste Type* \\
\hline Battery & Recyclable \\
\hline
\end{tabular}

* Ordinary, Scrap Metal, Asbestos, PCB, Salvageable, Hazardous, Radioactive, Mixed, Unknown, Other

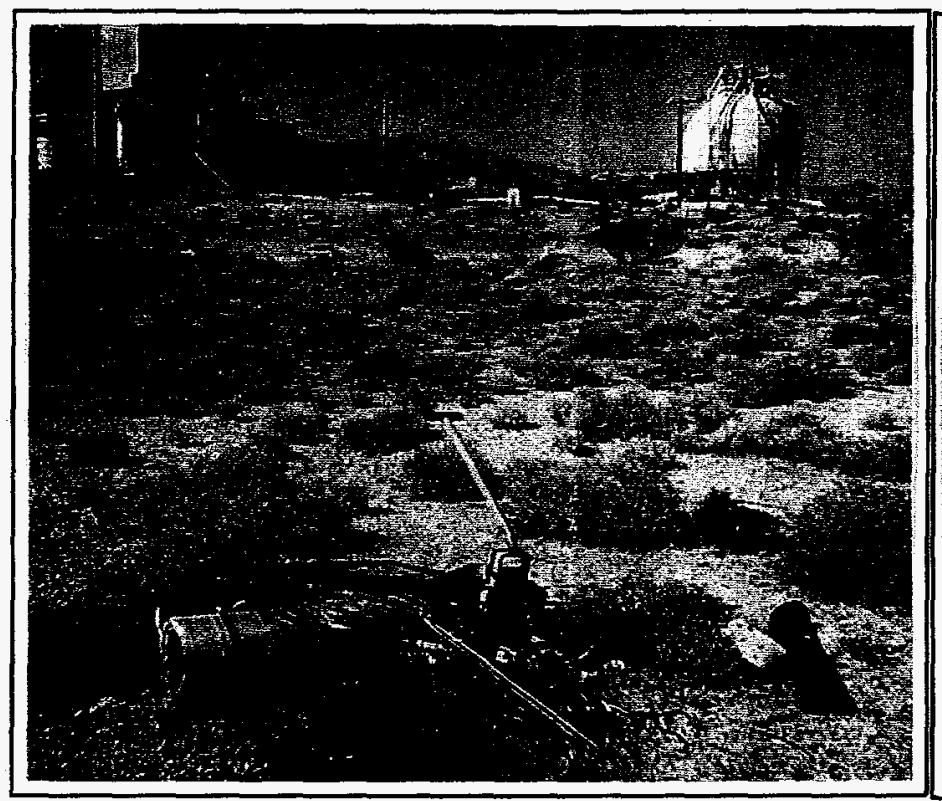

CAS Prior To Cleanup

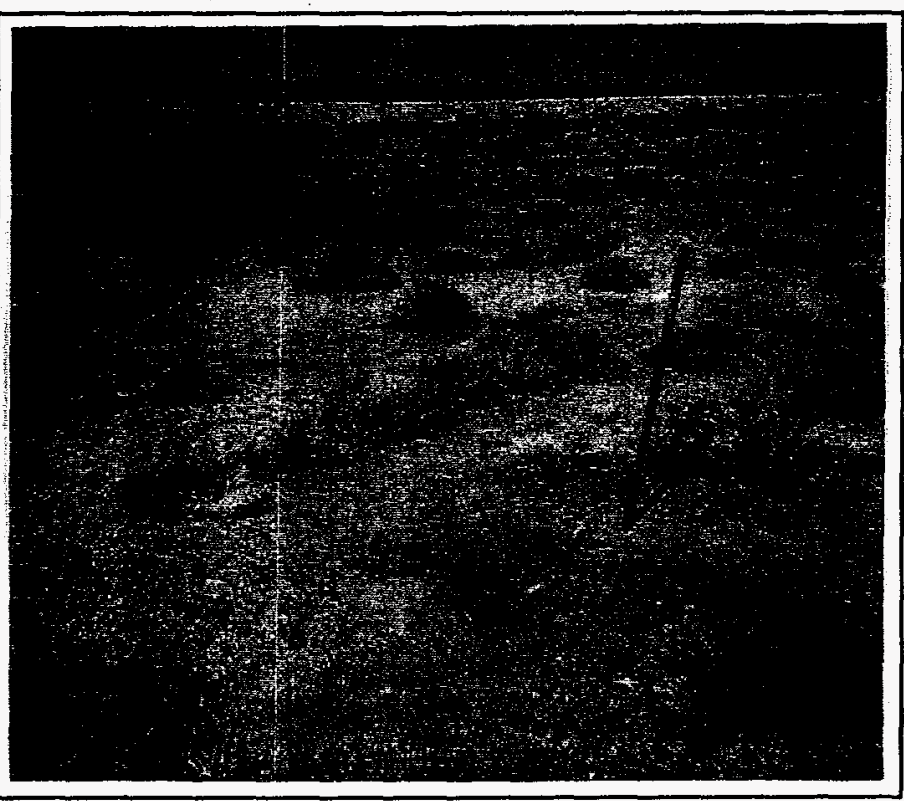

CAS After Cleanup

Current Site Description/Observations: Field crews identified this site while conducting GPS coordinates on a nearby CAS (25-26-21) on 16-AUG-93. The site consisted of a broken lead-acid battery and a debris pile. NTS personnel verified that the battery and debris were still present. The broken battery, and other lead fragments found nearby, were packaged and delivered to Fleet Operations for recycling. The CAS debris, including debris from nearby 25-26-21, was retrieved and disposed at the Area 23 Landfill. Additional lead bricks and sheets found in the vicinity were recycled through Property and Supply.

No Further Action Required at Corrective Action Site

C. Carlos Gonzales

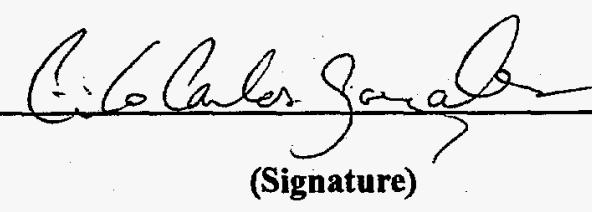
$1-6.98$ 


\section{FFACO CORRECTIVE ACTION Site Housekeeping Closure VERIFICATION Form}

Closure Verification Date: 30-APR-97

CAS Number: $25-27-02$

General Location: R-MAD Building

Latitude:

Longitude:

\author{
CAU Number: 354 \\ Elevation: \\ Northing: 752,500 \\ Easting: 652,000
}

Coordinate/Elevation Data Obtained from Garmen 40 Global Position System: Accuracy is within $300 \mathrm{ft} \mathrm{Horizontal} \mathrm{-} \mathrm{Vertical} \mathrm{Varies} \mathrm{with} \mathrm{Locality}$

Site Access Route: From Mercury, proceed SW on Jackass Flats Rd to Area 25, through Gate 500. Proceed north on C-Rd and turn right (east) on G-Rd. Follow G-Rd towards the R-MAD complex. The CAS is located 100 yards NE of the main R-MAD building at the base of a camera tower.

\begin{tabular}{|l|l|}
\hline \multicolumn{1}{|c|}{ Waste Item(s) Originally at Site } & \multicolumn{1}{c|}{ Apparent Waste Type* $^{*}$} \\
\hline Drums & PCB \\
\hline
\end{tabular}

" Ordinary, Scrap Metal, Ashestos, PCB, Salvageable, Hazardous, Radioactive, Mixed, Unknown, Other

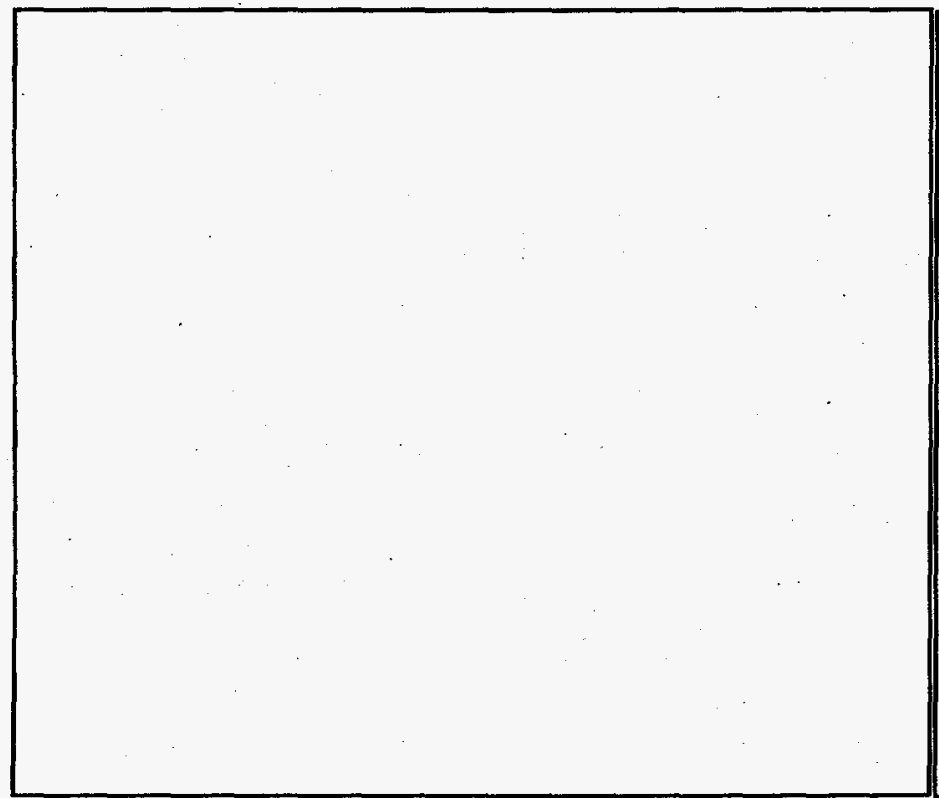

No CAS Photo Available Prior To Cleanup

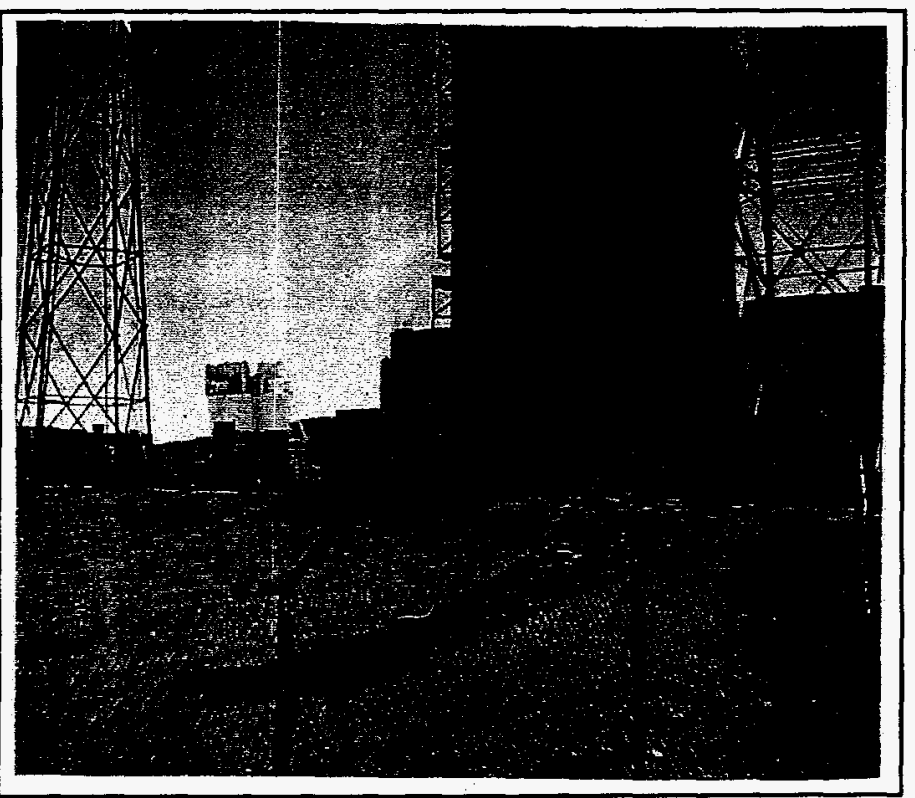

CAS After Cleanup

Current Site Description/Observations: Originally identified on 30-NOV-90, file documentation indicates that two drums were removed in 1991 and transported to the Area 6 PCB Storage Facility prior to being shipped offsite to an EPA-permitted disposal facility. NTS personnel verified that the drums were no longer there. Lead bricks, found outside the fenced compound, were retrieved and recycled through Property and Supply on 16-SEP-97 along with lead materials retrieved from CAS 25-24-18 (Engine Test Stand \#1).

No Further Action Required at Corrective Action Site

C. Carlos Gonzales

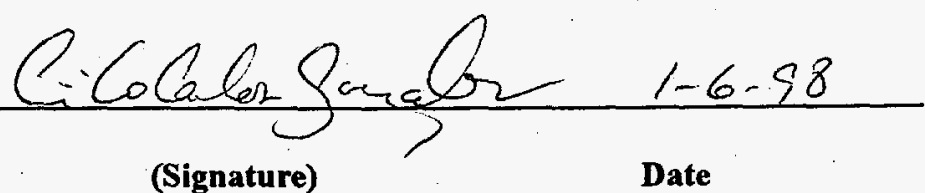

Corrective Action Coordinator/Designee

(Signature)

Date 


\section{FFACO CORRECTIVE ACTION SITE HoUSEKEEPING ClosURE VERIFICATION FORM}

Closure Verification Date: $30-A P R-97$

CAS Number: 25-99-15

General Location: E-MAD Building

Latitude:

Longitude:

\author{
CAU Number: 354 \\ Elevation: \\ Northing: $748,794.905$ \\ Easting: $606,387.413$
}

Coordinate/Elevation Data Obtained from Garmen 40 Global Position System: Accuracy is within $300 \mathrm{ft}$ Horizontal - Vertical Varies with Locality

Site Access Route: From Mercury, proceed SW on Jackass Flats Rd to Area 25, through Gate 500. Proceed north on C-Rd and turn left west) on H-Rd. Follow H-Rd towards the E-MAD complex and turn left (south) on the E-MAD road. The CAS is located inside the Bonded Storage Room.

\begin{tabular}{|l|l|}
\hline \multicolumn{1}{|c|}{ Waste Item(s) Originally at Site } & \multicolumn{1}{c|}{ Apparent Waste Type* $^{-1}$} \\
\hline Highway Flares & Hazardous (Explosive) \\
\hline
\end{tabular}

* Ordinary, Scrap Metal, Asbestos, PCB, Salvageable, Hazardous, Radioactive, Mired, Unknown, Other

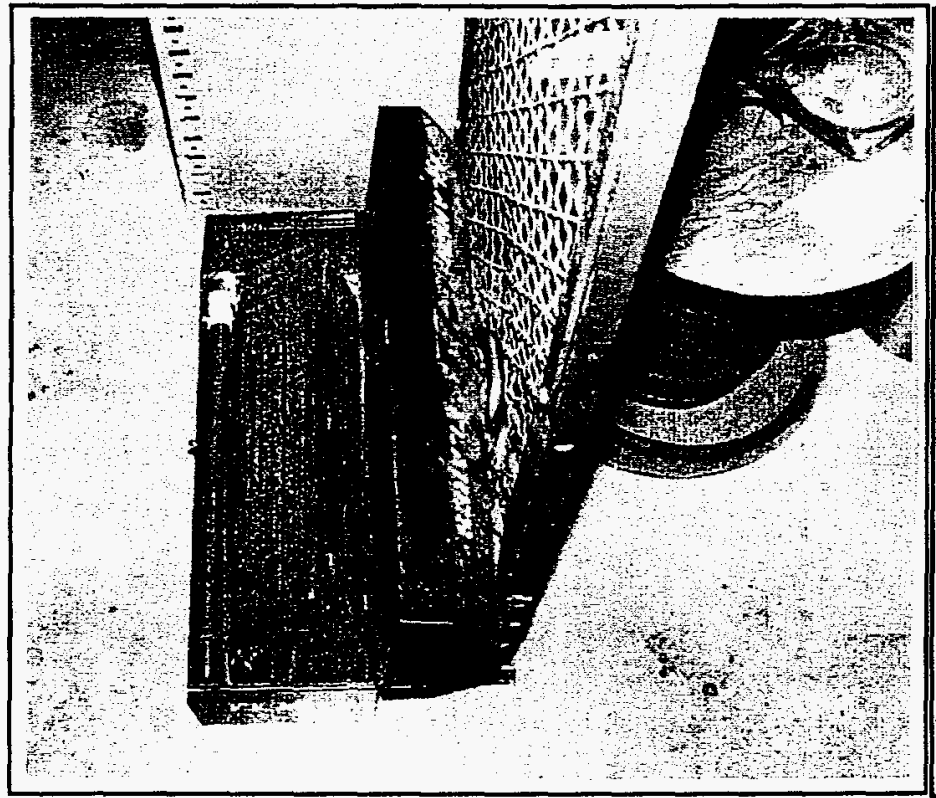

CAS Prior To Cleanup

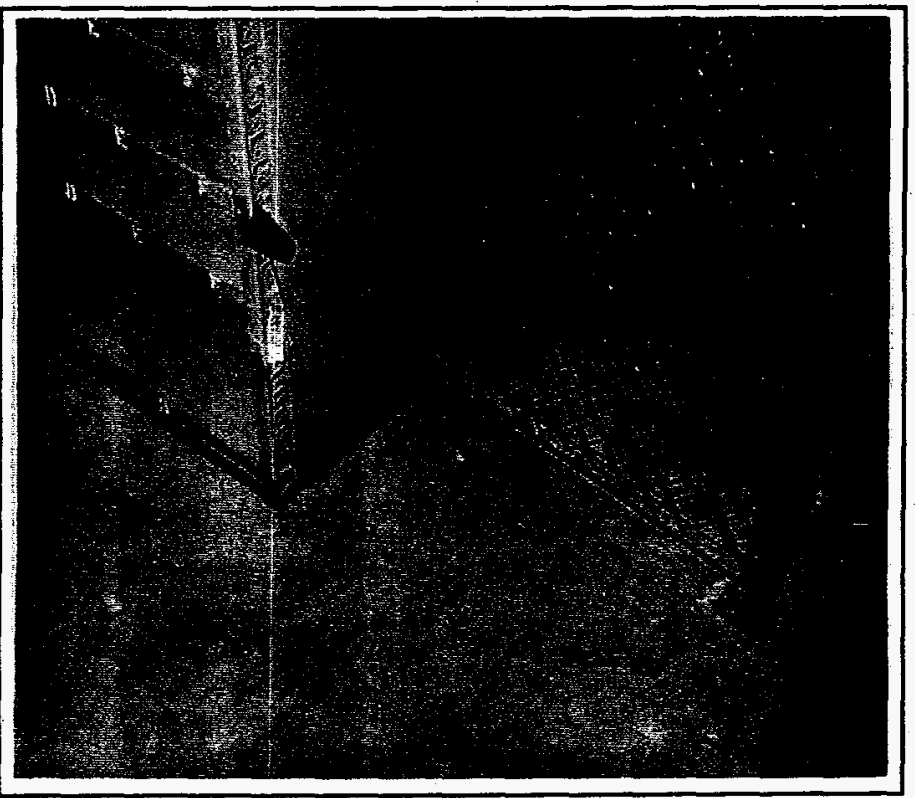

CAS After Cleanup

Current Site Description/Observations: Originally identified on 18-DEC-90, NTS personnel verified that the flares were no longer present. A CAS tag marks the former location near the supply cabinet in the storage room.

No Further Action Required at Corrective Action Site

C. Carlos Gonzales

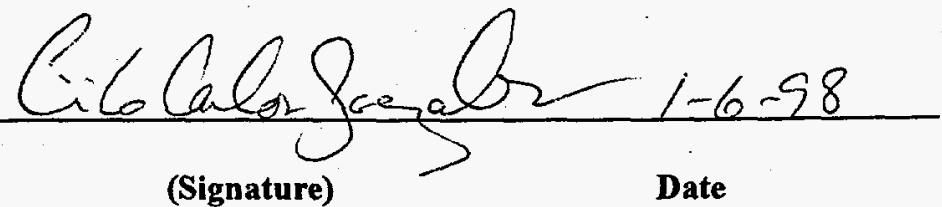

Corrective Action Coordinator/Designee

(Signature)

Date 


\section{FFACO CORRECTIVE ACTION SITE HOUSEKEEPING ClOSURE VERIFICATION FORM}

Closure Verification Date: $\quad$ 14-OCT-97

CAS Number: 25-99-17

General Location: Test Cell A

Latitude:

Longitude:

\author{
CAU Number: 354 \\ Elevation: \\ Northing: $756,932.260$ \\ Easting: $619,386.500$
}

Coordinate/Elevation Data Obtained from Garmen 40 Global Position System: Accuracy is within $300 \mathrm{ft}$ Horizontal - Vertical Varies with Locality

Site Access Route: From Mercury, proceed SW on Jackass Flats Rd to Area 25, through Gate 500. Proceed north on C-Rd and follow as oad becomes F-Rd, curving eastward. Test Cell A is located on the left (north) side of the road. The CAS lies inside the fenced compound, to he left (west) of the main gate. A marker identifies the location.

\begin{tabular}{|l|l|}
\hline \multicolumn{1}{|c|}{ Waste Item(s) Originally at Site } & \multicolumn{1}{c|}{ Apparent Waste Type* $^{*}$} \\
\hline (4) Gas Bottles & Unknown \\
\hline
\end{tabular}

* Ordinary, Scrap Metal, Asbestos, PCB, Salvageable, Hazardous, Radioactive, Mixed, Unknown, Other

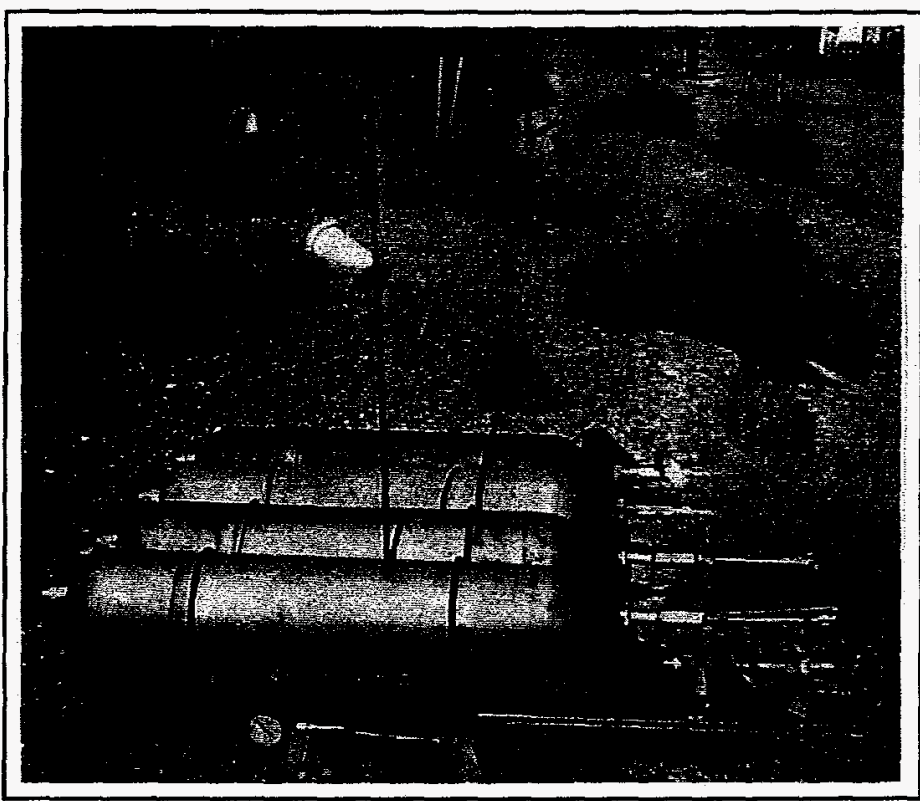

CAS Prior To Cleanup

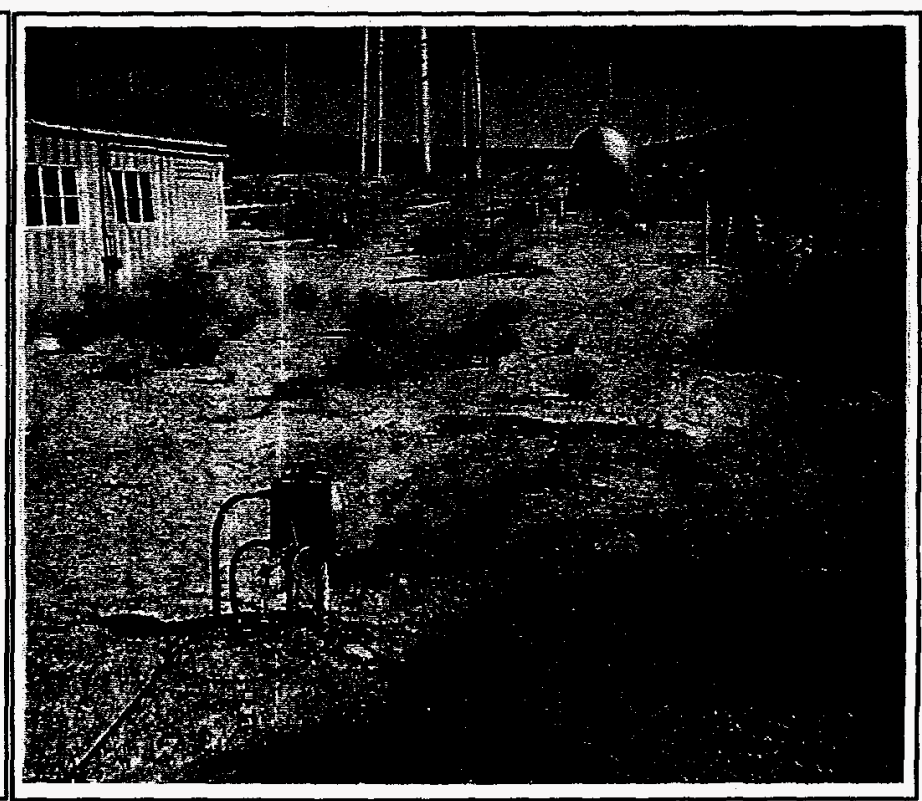

CAS After Cleanup

Current Site Description/Observations: NTS personnel verified that the gas cylinders were still at this location. After determining that three of the bottles were empty, Industrial Hygiene personnel sampled gas from the fourth cylinder and determined that it was only compressed air. The cylinders were disposed at the Area 23 Landfill after the air was vented out. Surrounding materials retrieved for disposal included of wood, steel, and aluminum debris.

No Further Action Required at Corrective Action Site

C. Carlos Gonzales

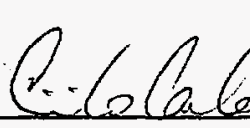

Corrective Action Coordinator/Designee

(Signature)

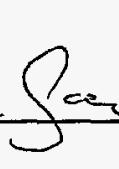

$1 \frac{\text { C. Carlos Gonzales }}{\text { Corrective Action Coordinator/Designee }}$




\title{
FFACO CORRECTIVE ACTION Site HOUSEKEEPING CLOSURE VERIFICATION FORM
}

Closure Verification Date: 28-SEP-97

$\begin{aligned} \text { CAS Number: } & 26-99-02 \\ \text { General Location: } & \text { Pluto Facility } \\ \text { Latitude: } & \\ \text { Longitude: } & \end{aligned}$

\author{
CAU Number: 354 . \\ Elevation: \\ Northing: \\ Easting:
}

Coordinate/Elevation Data Obtained from Garmen 40 Global Position System: Accuracy is within 300 ft Horizontal - Vertical Varies with Locality

Site Access Route: From Mercury, proceed N on Mercury Hwy to Cane Springs Rd. Turn left (west) on Cane Springs Rd for $6.5 \mathrm{mi}$ to Pluto Rd. Turn right (east) then left (north) towards the Pluto Facility, passing through the main gate and proceeding to a field on the north side of the building. A marker identifies the CAS.

\begin{tabular}{|l|l|}
\hline \multicolumn{1}{|c|}{ Waste Item(s) Originally at Site } & \multicolumn{1}{c|}{ Apparent Waste Type* $^{*}$} \\
\hline (4) Smoke Pots & Hazardous (Explosive) \\
\hline
\end{tabular}

- Ordinary, Scrap Metal, Asbestos, PCB, Salvageable, Hazardous, Radioactive, Mixed, Unknown, Other

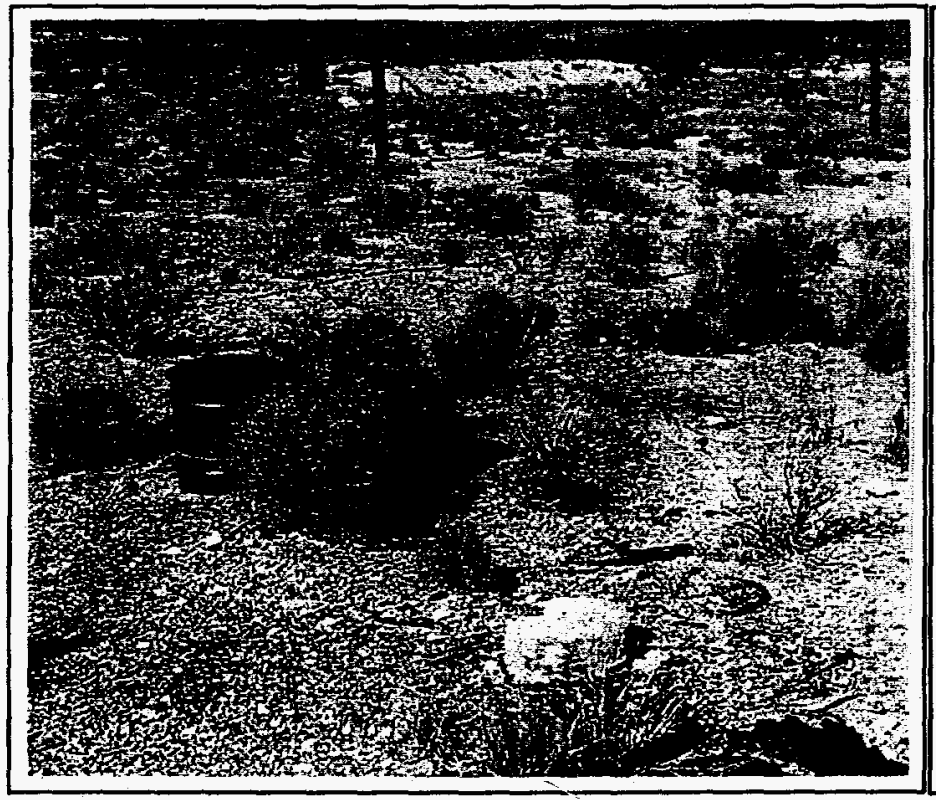

CAS Prior To Cleanup

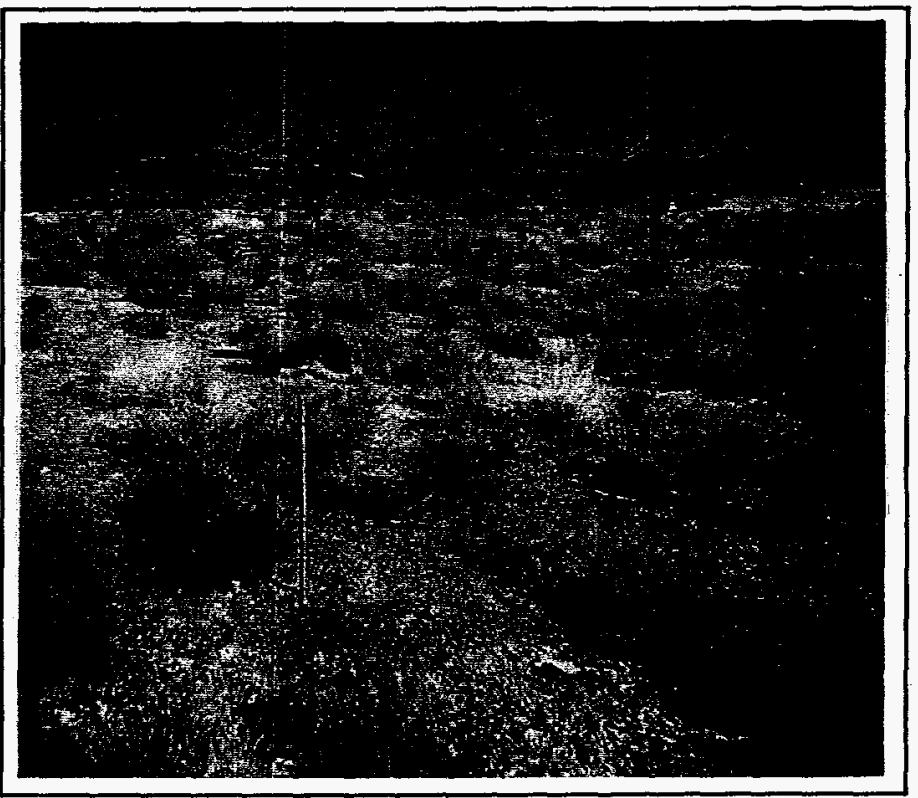

CAS After Cleanup

Current Site Description/Observations: Originally identified on 30-OCT-90, NTS personnel verified that most of the smoke pot debris had been removed, but some still remained along with miscellaneous debris. The debris was disposed at the Area 23 Landfill, and the remaining smoke pots were disposed at the Area 11 Explosive Ordnance Disposal Unit. Additional debris (empty containers), found near the Cane Springs Rd/Mercury Hwy intersection, were also retrieved for disposal.

No Further Action Required at Corrective Action Site

C. Carlos Gonzales

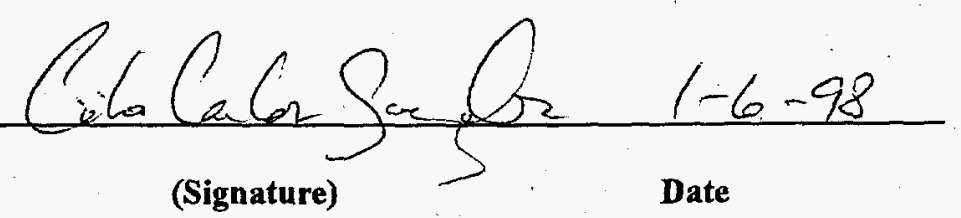




\section{FFACO CORRECTIVE ACTION SITE HOUSEKEEPING ClOSURE VERIFICATION FORM}

Closure Verification Date: $22-A U G-96$

CAS Number: 27-22-01

General Location: Able Compound Access Rd

Latitude:

CAU Number: 354

Longitude:

Elevation:

Northing:

Easting:

Coordinate/Elevation Data Obtained from Garmen 40 Global Position System: Accuracy is within $300 \mathrm{ft}$ Horizontal - Vertical Varies with Locality

Site Access Route: From Mercury, proceed N on Mercury Hwy to Cane Springs Rd. Turn left (west) on Cane Springs Rd for $6.1 \mathrm{mi}$ to he Area 27 turnoff. Turn left (south) and proceed $1.4 \mathrm{mi}$ to Gate 250. After obtaining clearance for entry, proceed for $1.4 \mathrm{mi}$, then turn left (east) for $0.2 \mathrm{mi}$ to CAS.

\begin{tabular}{|l|l|}
\hline \multicolumn{1}{|c|}{ Waste Item(s) Originally at Site } & \multicolumn{1}{c|}{ Apparent Waste Type* $^{*}$} \\
\hline (5) Drums & Unknown \\
\hline
\end{tabular}

* Ordinary, Scrap Metal, Asbestos, PCB, Salvageable, Hazardous, Radioactive, Mixed, Unknown, Other

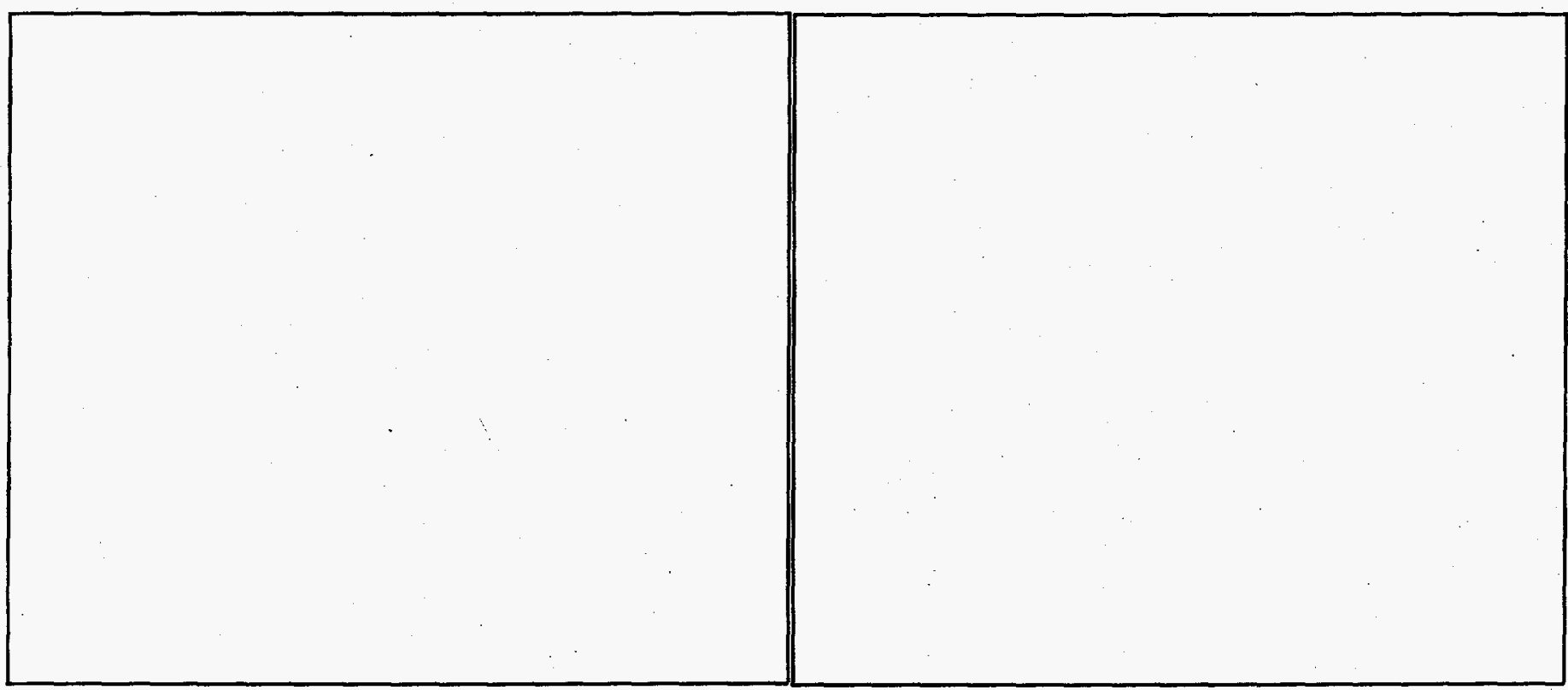

No CAS Photos Available

No CAS Photos Available

Current Site Description/Observations: Originally identified by field crews, the site consisted of a pallet of 55-gallon drums. One drum was rusted through its base, and another drum was heavily bowed out. In August 1996, field crews found that the pallet and drums had been removed from the area. Due to security restrictions for entering this area, N.TS Housekeeping cleanup personnel did not attempt to enter the Able Compound and used existing process knowledge to verify the CAS status.

No Further Action Required at Corrective Action Site

C. Carlos Gonzales

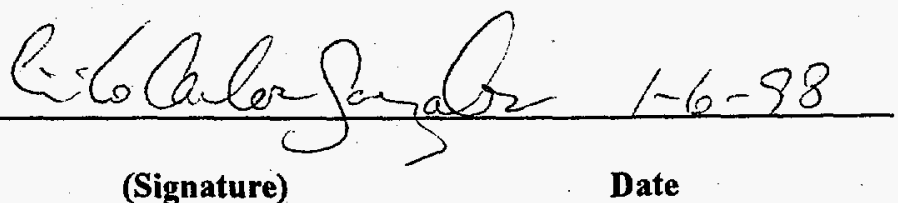




\title{
FFACO CORRECTIVE ACTION SITE HOUSEKEEPING CLOSURE VERIFICATION FORM
}

Closure Verification Date: 26-AUG-96

\author{
CAS Number: 27-22-02 \\ General Location: EOD Area \\ Latitude: \\ CAU Number: 354 \\ Longitude: \\ Elevation: \\ Northing: \\ Easting:
}

Coordinate/Elevation Data Obtained from Garmen 40 Global Position System: Accuracy is within $300 \mathrm{ft}$ Horizontal - Vertical Varies with Locality

Site Access Route: From Mercury, proceed N on Mercury Hwy to Cane Springs Rd. Turn left (west) on Cane Springs Rd for $6.1 \mathrm{mi}$ to he Area 27 turnoff. Turn left (south) and proceed $1.4 \mathrm{mi}$ to Gate 250. After obtaining clearance for entry, proceed for $2.1 \mathrm{mi}$ to the gate marked "B-5", then turn left (east) for 0.3 mi to CAS.

\begin{tabular}{|l|l|}
\hline \multicolumn{1}{|c|}{ Waste Item(s) Originally at Site } & \multicolumn{1}{c|}{ Apparent Waste Type* } \\
\hline Drum; Fuel Can & Unknown \\
\hline
\end{tabular}

* Ordinary, Scrap Metal, Asbestos, PCB, Salvageable, Hazardous, Radioactive, Mixed, Unknown, Other.

Current Site Description/Observations: Originally identified by field crews, the site consisted of debris, including a drum and fuel can. It is not known if they were empty, or if they had contents. In August 1996, field crews found that the debris and containers had been removed from the area. A marker was placed 100 feet inside a locked fence area (at the former drum site). Due to security restrictions for entering this area, NTS Housekeeping cleanup personnel did not attempt to enter the EOD Area and used existing process knowledge to verify the CAS status.

No Further Action Required at Corrective Action Site

C. Carlos Gonzales




\section{DISTRIBUTION LIST}

U. S. Department of Energy, Nevada Operations Office

P. O. Box 98518

Las Vegas, NV 89193-8518

J. L. Appenzeller-Wing

Public Reading Room

Technical Information Resource Center

U. S. Department of Energy,

Office of Scientific and Technical Information

175 Oak Ridge Turnpike

P. O. Box 62

Oak Ridge, TN 37831

Bechtel Nevada

P. O. Box 98521

Las Vegas, NV 89193-8521

D. K. Cowser

J. R. Kannard

C. C. Gonzales

\section{IT Corporation}

4330 South Valley View, Suite 114

Las Vegas, NV 89103-4047

R. C. Silver 